\title{
Occupational Safety and Health among Carpet Factory Workers in a District of Nepal
}

\author{
Raj Kumar Subedi ${ }^{*}$, Subin Banamala ${ }^{2}$ \\ ${ }^{1}$ Central Institute of Science and Technology (CIST College), Kathmandu, Nepal \\ ${ }^{2}$ Little Buddha College of Health Science, Kathmandu, Nepal \\ Email: rajkumarsubedi@gmail.com
}

Received 23 August 2015; accepted 11 September 2015; published 14 September 2015

Copyright (C) 2015 by authors and OALib.

This work is licensed under the Creative Commons Attribution International License (CC BY). http://creativecommons.org/licenses/by/4.0/

(c) (i) Open Access

\section{Abstract}

Occupational safety and health is a neglected area in small scale cottage factories in Nepal. A cross-sectional study was conducted in 10 small scale carpet factories in Bhaktapur district of Nepal among 100 workers to find out their occupational health and safety status. The study revealed that majority of the workers were females $(57 \%)$ and more than half $(52 \%)$ of the workers were aged 20 - 30 years. The duration of work in a day ranged from 8 to 12 hours and majority were weavers (58\%). About three in four $(77 \%)$ worked outside the factory as well. None of them received health education at work and none of the factories had medical treatment facilities and had only basic first aid treatment. Similarly, $80 \%$ were not found to be using any personal protective equipment (PPE) during work. A total of $90 \%$ workers regarded the dust control measures in their factory as poor; $90 \%$ regarded ventilation as poor, $60 \%$ reported fire management preparedness as poor; and $30 \%$ perceived the first aid treatment services as poor. Majority of them (84\%) said they had experienced some health problems at work. The most commonly reported health problems were backache/joint ache $(63.1 \%)$, eye irritations $(40.48 \%)$, prolonged headache $(40.48 \%)$, chest pain $(38.1 \%)$, and skin irritation $(23.81 \%)$. Only $27.38 \%$ of them informed the authority after experiencing problems; $65.22 \%$ of those who reported their problems received treatment. Interestingly, $10 \%$ said it was not big deal to have health problems while working in the carpet factory. Further comparative and analytical studies are recommended to explore the occupational health status in small scale factories in Nepal.

\section{Keywords}

Carpet Factories, Health, Nepal, Occupation, Safety

Subject Areas: Psychology, Public Health

\footnotetext{
"Corresponding author.
} 


\section{Introduction}

Geographically, Nepal is landlocked between two of the largest countries of the world; China and India, which are the third and the seventh largest countries of the world, respectively [1]. Occupational safety is a major issue for employees, and how management deals with this issue is of both academic and practical significance [2]. In Nepal, the second long-term health plan (1997-2017) has identified occupational health as one of the emerging priority health issues [3]. Occupational safety and health is the science of anticipation, recognition, evaluation and control of hazards arising in or from the workplace, which could impair the health and well-being of workers, and also impact the surrounding communities and the environment [4]. Very little information is available on their workplaces and their work-related health problems in Nepal [3].

Small-scale industries are a widespread, fundamental and essential form of production. In many countries, small-scale industries are the main providers of new employment. In addition, these industries play an outstanding part in economic development of countries by producing export products [5]. Working conditions for the majority of the world's workers do not meet the minimum standards and guidelines set by international agencies. The International Labor Organization (ILO) conventions are intended to guide all countries in the promotion of workplace safety and in managing occupational health and safety programs. ILO conventions and recommendations on occupational safety and health are international agreements that have legal force only if they are ratified by ILO member states [6].

Of the total 3 billion workers in the world, over $85 \%$ work and live without having access to occupational health services (OHS). In many countries on all continents, occupational health services may cover only $5 \%$ of the workforce. Statistics on coverage are also very unreliable and subject to variations in the definitions and measurement methods [7]. Improving occupational health and safety is in the best interests of all governments, employers and workers, and measures to make improvements should be discussed and agreed among the ILO constituents. Successful health and safety practice is based on collaboration and good will, as well as taking on board the opinions of the people concerned [8]. The study will thus help identify the existing status of occupational health and safety among carpet factory workers and will be useful for researchers, policy makers, academicians and other relevant stakeholders.

\section{Methods and Materials}

A descriptive cross-sectional study was carried out from May 2011 to October 2011 in selected carpet factories of Bhaktapur district. The workers were selected randomly from 10 factories, 10 from each factory that yielded a total of 100 study subjects. Interviews were conducted with the working staff in the selected factories. The questionnaire was pretested among 10 workers in Lalitpur district. The managers and supervisors were not included in the study. Verbal informed consent was taken from the participants before taking the interview. Privacy and confidentiality was ensured during the study. The respondents were also not forced to answer any of the questions. After data collection, data was entered in MS-EXCEL 2007, which was further analyzed using SPSS version 16 software. Descriptive statistics was only used to analyze the data because of the limited sample size.

\section{Results}

\subsection{Background Information}

Fifty two percent were aged 20 - 30 years and 23\% were of age 10 - 20 years. Majority of the workers were females (57\%) and majority (67\%) were Janajatis who are the indigenous people living in the district. One in four (25\%) of the factory workers were unmarried. Looking at the marital status, $40 \%$ were from nuclear families. Similarly, when they were asked about the distance of place of residence from the factory, it was revealed that $84 \%$ of the workers were living inside the factory (Table 1 ).

\subsection{Job Characteristics}

As seen in Table 2, 44\% (i.e. 44 out of 100) had other family members working in the factory. Majority of the factory workers were weavers (58\%) and $64 \%$ had worked for 1 to 5 years. All workers worked 6 days a week and the number of working hours ranged from 8 to 12 hours a day. Majority of the workers said they worked in other places outside the factory as well (77\%); and around $90 \%$ of them (69 out of 77) were involved in carpet 
Table 1. Socio-demographic information of the respondents.

\begin{tabular}{|c|c|c|}
\hline Demographic characteristics $(\mathrm{n}=100)$ & Frequency & Percentage \\
\hline \multicolumn{3}{|l|}{ Age } \\
\hline 10 - 20 years & 23 & 23 \\
\hline 20 - 30 years & 52 & 52 \\
\hline $30-40$ years & 22 & 22 \\
\hline 40 - 50 years & 3 & 3 \\
\hline \multicolumn{3}{|l|}{ Sex } \\
\hline Male & 43 & 43 \\
\hline Female & 57 & 57 \\
\hline \multicolumn{3}{|l|}{ Ethnicity } \\
\hline Janajatis & 67 & 67 \\
\hline Non-Dalit Terai & 28 & 28 \\
\hline Dalit & 3 & 3 \\
\hline Upper caste & 2 & 2 \\
\hline \multicolumn{3}{|l|}{ Marital status } \\
\hline Unmarried & 25 & 25 \\
\hline Married & 75 & 75 \\
\hline \multicolumn{3}{|l|}{ Family type } \\
\hline Nuclear & 40 & 40 \\
\hline Joint & 52 & 52 \\
\hline Extended & 8 & 8 \\
\hline \multicolumn{3}{|l|}{ Distance of factory from place of residence } \\
\hline Living within factory & 84 & 84 \\
\hline Within 30 minutes & 7 & 7 \\
\hline $30 \mathrm{~min}^{-1}$ hour & 5 & 5 \\
\hline More than one hour & 4 & 4 \\
\hline
\end{tabular}

Table 2. Job characteristics of the respondents.

\section{Characteristics}

Other family members working in the factory $(\mathrm{n}=100)$
No

Number of family members working $(n=44)$

\section{Frequency}

44

56

18

12

9

5
Percent

44

56

40.91

27.27

20.45

11.36 


\section{Continued}

Nature of job $(n=100)$

$\begin{array}{ccc}\text { Store related } & 10 & 10 \\ \text { Weaving } & 58 & 58 \\ \text { Spinning } & 16 & 16 \\ \text { Dying related } & 16 & 16\end{array}$

Satisfied with the job $(\mathrm{n}=100)$

Yes

No

Years of work in the factory $(n=100)$

$$
1-5
$$

$5-10$

Working days in a week $(\mathrm{n}=100)$

Work hours in a day $(\mathrm{n}=100)$

8

10

Working at other places $(\mathrm{n}=100)$

$$
\text { Yes }
$$

Provision of periodic health examination in the factory $(n=100)$

$$
\text { Yes }
$$

Provision of medical treatment besides first aid in the factory $(\mathrm{n}=100)$

Yes

No

Provision of sick leave

Yes

No

Provision of health education for occupational safety
0

100

100

100

100

0

0
0

100

10

58

6

16


related work. All the workers said they were not provided the health education at work and all of them said there was no any provision of medical treatment in addition to the basic first aid services. All the workers said that there was a provision of sick leave in the factory.

\subsection{Attitude of Carpet Factory Workers on Occupational Health Safety}

Of total workers, $95 \%$ had the view that periodic health examination is necessary for factory workers; $95 \%$ said First aid treatment is necessary; 92\% said personal protective equipment (PPE) should be used regularly; 92\% said the non-use of PPE can cause health problems; $90 \%$ said occupational health and safety is the role of both the owner and workers and $10 \%$ had the view that having health problems while working in the factory is not a big deal (Table 3).

\subsection{Occupation Safety at Work}

Of total workers, $80 \%$ were not found to be using any safety measures or PPE. Of 20 workers who were using some measures, the PPE used were gloves (85\%), boots (35\%), aprons (30\%) and mask (15\%). Of 20 workers who used the PPE, 25\% used it rarely, 50\% used sometimes and 25\% used always. When asked whether they were ever supervised by their boss at work, $10 \%$ said they were never supervised. The workers were also asked about their perceived quality of occupational safety at work in the factory. A total of $90 \%$ workers perceived the dust control measures in their factory as poor; $90 \%$ reported ventilation facility as poor, $60 \%$ reported fire management preparedness as poor; and 30\% perceived the first aid treatment services as poor (Table 4).

Table 3. Attitude of workers on occupational health safety $(n=100)$.

\begin{tabular}{|c|c|c|}
\hline Statements & Frequency & Percent \\
\hline \multicolumn{3}{|c|}{ Periodic health examination for factory workers is necessary } \\
\hline Yes & 95 & 95 \\
\hline No & 5 & 5 \\
\hline \multicolumn{3}{|l|}{ First aid treatment is necessary } \\
\hline Yes & 94 & 94 \\
\hline No & 6 & 6 \\
\hline \multicolumn{3}{|c|}{ Personal protective equipment should be used regularly } \\
\hline Yes & 92 & 92 \\
\hline no & 0 & 0 \\
\hline Don’t know & 8 & 8 \\
\hline \multicolumn{3}{|c|}{ Non-use of PPP can cause occupational health problems } \\
\hline Yes & 92 & 92 \\
\hline No & 1 & 1 \\
\hline Don’t know & 7 & 7 \\
\hline \multicolumn{3}{|c|}{ Occupational health safety is the role of } \\
\hline Factory owner only & 10 & 10 \\
\hline Worker only & 0 & 0 \\
\hline Both the owner and worker & 90 & 90 \\
\hline \multicolumn{3}{|c|}{ Having health problems is not a big deal in factory work } \\
\hline Agree & 10 & 10 \\
\hline Disagree & 86 & 86 \\
\hline Don’t know & 4 & 4 \\
\hline
\end{tabular}


Table 4. Condition of occupational safety at work.

\begin{tabular}{|c|c|c|}
\hline Characteristics & Frequency & Percent \\
\hline \multicolumn{3}{|c|}{ Used any safety measures $(n=100)$} \\
\hline Yes & 20 & 20 \\
\hline No & 80 & 80 \\
\hline \multicolumn{3}{|c|}{ Type of safety measures $(n=20)$} \\
\hline Gloves & 17 & 85 \\
\hline Mask & 3 & 15 \\
\hline Apron & 6 & 30 \\
\hline Boots & 7 & 35 \\
\hline \multicolumn{3}{|c|}{ Frequency of use of any safety measures $(n=20)$} \\
\hline Rarely & 5 & 25 \\
\hline Sometimes & 10 & 50 \\
\hline Always & 5 & 25 \\
\hline \multicolumn{3}{|c|}{ Supervision by manager at work $(n=100)$} \\
\hline Yes & 90 & 90 \\
\hline No & 10 & 10 \\
\hline \multicolumn{3}{|c|}{ Self-Reported quality of dust control measure in the factory $(\mathrm{n}=100)$} \\
\hline Good & 0 & 0 \\
\hline Average & 10 & 10 \\
\hline Poor & 90 & 90 \\
\hline \multicolumn{3}{|c|}{ Self-reported condition of ventilation in the factory $(n=100)$} \\
\hline Good & 0 & 0 \\
\hline Average & 10 & 10 \\
\hline Poor & 90 & 90 \\
\hline \multicolumn{3}{|c|}{ Self-reported quality of fire management in the factory $(n=100)$} \\
\hline Good & 0 & 0 \\
\hline Average & 40 & 40 \\
\hline Poor & 60 & 60 \\
\hline \multicolumn{3}{|c|}{ Self-reported quality of first aid facility in the factory $(n=100)$} \\
\hline good & 10 & 10 \\
\hline Average & 60 & 60 \\
\hline poor & 30 & 30 \\
\hline
\end{tabular}

\subsection{Health Problems Faced by the Workers and Health Seeking Behavior}

Majority (84\%) said they had experienced the health problems after working in the factory. The most common reported health problems were backache/joint ache (63.1\%), eye irritations $(40.48 \%)$, prolonged headache (40.48\%), chest pain (38.1\%), skin irritation (23.81\%), GI infections (17.86\%), prolonged cough (14.29\%), loss 
of appetite (5.95\%) and fainting (3.57\%). Only a few of them informed the authority after experiencing health problems (27.38\%); 65.22\% were not provided treatment benefits after informing the authority; and of those who were treated, only a third of them (37.5\%) were treated in the hospital (Table 5).

\section{Discussion}

It is commonly assumed that occupational injuries are less of a problem in developing countries because there is less industrialization. Spot studies reveal, however, that injuries are a serious problem among miners, agricultural workers, and industrial workers in most countries [9]. This study also revealed that there exist occupational health problems among the factory workers. Majority (84\%) of the workers had experienced at least one health problem while working in the factory.

Carpet hand-weaving is a common practice in countries such as, India, China, Turkey, Iran, and Pakistan and is then transported to other countries for selling. Hand woven carpets are produced in home-based workshops categorized as informal small-scale industry. The work is often organized around families and carried out in homes. As most of the setups are installed in homes, womenfolk and children also contribute to the work [10]. This study also showed that $44 \%$ of the carpet factory workers had their families working in the same occupation. The number of family members working ranged from 1 to 4 .

Table 5. Health problems faced by the workers.

\begin{tabular}{|c|c|c|}
\hline Characteristics & Frequency & Percent \\
\hline \multicolumn{3}{|c|}{ Experienced health problems after working in the factory $(n=100)$} \\
\hline Yes & 84 & 84 \\
\hline No & 16 & 16 \\
\hline \multicolumn{3}{|c|}{ Nature of health problems $(\mathrm{n}=84)$} \\
\hline Prolonged cough & 12 & 14.29 \\
\hline Skin infections & 20 & 23.81 \\
\hline Back ache/joint ache & 53 & 63.1 \\
\hline Chest pain & 32 & 38.1 \\
\hline Eye irritations & 34 & 40.48 \\
\hline Prolonged headache & 34 & 40.48 \\
\hline Gastro-intestinal infections & 15 & 17.86 \\
\hline Loss of appetite & 5 & 5.95 \\
\hline Fainting & 3 & 3.57 \\
\hline \multicolumn{3}{|c|}{ Informed health problems to the authority $(\mathrm{n}=84)$} \\
\hline Yes & 23 & 27.38 \\
\hline No & 61 & 72.62 \\
\hline \multicolumn{3}{|c|}{ Treatment provided by authority after informing $(\mathrm{n}=23)$} \\
\hline Yes & 8 & 34.78 \\
\hline No & 15 & 65.22 \\
\hline \multicolumn{3}{|c|}{ Type of treatment after informing $(\mathrm{n}=8)$} \\
\hline At hospital & 3 & 37.5 \\
\hline At health post & 5 & 62.5 \\
\hline
\end{tabular}


The prevalence of work-related musculoskeletal disorders is increasing worldwide. The association between job type and the specific activities within jobs that predispose to the risk of developing such disorders is well documented for developed countries. The prevalence of any work-related musculoskeletal disorders in developing countries ranges from 37\% among a general population-based sample of workers through to $92 \%$ among nurses [11]. This study also showed $63.1 \%$ (50 out of 84 ) of those having experienced any problems had the problems of backache/joint ache.

Injuries are very common among the factory workers [12] [13]. A study done in Pakistan among carpet factory workers revealed that working children had significantly greater odds of joint pain, dry cough, cuts/bruises, Phalen's sign, and neck/shoulder abnormalities. Symptoms and signs of acute and repetitive injury and respiratory symptoms were more common among carpet-weaving children than their non-working peers [14]. Similarly, literatures suggest that females are found to be more affected with musculo-skeletal disorders than the males [15]. A cross-sectional study of respiratory disorders and atopy in Danish textile industry workers was conducted to survey respiratory symptoms throughout the textile industry which showed that carper factory workers are vulnerable to a number of respiratory illnesses [16]. This study done in Nepal also revealed several health problems among the carpet factory workers like body ache (63.1\%), eye irritation (40.5\%), prolonged headache (40.5\%), chest pain (38.1\%), skin problems (23.8\%), prolonged cough (14.3\%) and other health problems.

In a study done in Tanzania, there was low reported use of personal protective equipment [17]. Of total workers, $80 \%$ were not found to be using any safety measures or PPE. Of 20 workers who were using some measures, the PPE used were gloves (85\%), boots (35\%), aprons (30\%) and mask (15\%). Of 20 workers who used the PPE, $25 \%$ used it rarely, $50 \%$ used sometimes and $25 \%$ used always.

A study revealed that poor workstation design was a major risk factor for musculoskeletal symptoms in carpet weaving [18]. In this study, the workers were asked about their perceived quality of occupational safety at work in the factory. A total of $90 \%$ workers perceived the dust control measures in their factory as poor; $90 \%$ reported ventilation facility as poor, $60 \%$ reported fire management preparedness as poor; and 30\% perceived the first aid treatment services as poor.

\section{Limitations}

The study was conducted in an urban district and hence might not be able to capture the picture of all carpet factory workers in Nepal. The sample size of the study is also small. So, further researches with large and more representative sample can be done in the future in this area.

\section{References}

[1] Kansakar, V.B.S. (2012) Nepal, China and India Population Profile and Policies. http://104.236.33.185:8001/jspui/bitstream/123456789/26/1/Nepal,\%20China\%20and\%20India\%20population\%20prof iles\%20and\%20policies.pdf

[2] Barling, J., Kelloway, E.K. and Iverson, R.D. (2003) High-Quality Work, Job Satisfaction, and Occupational Injuries. Journal of Applied Psychology, 88, 276-283. http://dx.doi.org/10.1037/0021-9010.88.2.276

[3] Poudel, K.C., Jimba, M., Poudel-Tandukar, K. and Wakai, S. (2005) Lack of Occupational Health Research in Nepal. American Journal of Public Health, 95, 550. http://dx.doi.org/10.2105/ajph.2004.059543

[4] Joshi, S., Shrestha, S. and Vaidya, S. (2011) Occupational Safety and Health Studies in Nepal. International Journal of Occupational Safety and Health, 1, 19-26. http://dx.doi.org/10.3126/ijosh.v1i1.4725

[5] Choobineh, A., Shahnavaz, H. and Lahmi, M. (2004) Major Health Risk Factors in Iranian Hand-Woven Carpet Industry. International Journal of Occupational Safety and Ergonomics, 10, 65-78. http://dx.doi.org/10.1080/10803548.2004.11076596

[6] LaDou, J. (2003) International Occupational Health. International Journal of Hygiene and Environmental Health, 206, 303-313. http://dx.doi.org/10.1078/1438-4639-00226

[7] Rantanen, J. (2005) Basic Occupational Health Services. African Newsletter on Occupational Health and Safety, 15, 34.

[8] Alli, B.O. (2009) Fundamental Principles of Occupational Health and Safety. International Labour Organization (ILO), Geneva.

[9] Mohan, D. (1987) Injuries and the "Poor” Worker. Ergonomics, 30, 373-377. http://dx.doi.org/10.1080/00140138708969721 
[10] Wani, K.A. and Jaiswal, Y. (2011) Occupational Health Risk Factors in Carpet Industry: A Review. Asian Journal of Experimental Biological Sciences, 2, 135-139.

[11] Naidoo, R.N. and Haq, S.A. (2008) Occupational Use Syndromes. Best Practice \& Research Clinical Rheumatology, 22, 677-691. http://dx.doi.org/10.1016/j.berh.2008.04.001

[12] Akbar-Khanzadeh, F., Bisesi, M.S. and Rivas, R.D. (1995) Comfort of Personal Protective Equipment. Applied Ergonomics, 26, 195-198. http://dx.doi.org/10.1016/0003-6870(95)00017-7

[13] Rajbhandari, S. and Jha, N. (2013) Prevalence of Injuries amongst the People of Sonapur Village Development Committee Eastern Nepal. International Journal of Pharmaceutical \& Biological Archive, 4, 56-60.

[14] Awan, S., Nasrullah, M. and Cummings, K.J. (2010) Health Hazards, Injury Problems, and Workplace Conditions of Carpet-Weaving Children in Three Districts of Punjab, Pakistan. International Journal of Occupational and Environmental Health, 16, 113-119. http://dx.doi.org/10.1179/oeh.2010.16.2.113

[15] Nag, A., Vyas, H. and Nag, P. (2010) Gender Differences, Work Stressors and Musculoskeletal Disorders in Weaving Industries. Industrial Health, 48, 339-348. http://dx.doi.org/10.2486/indhealth.48.339

[16] Sigsgaard, T., Pedersen, O.F., Juul, S. and Gravesen, S. (1992) Respiratory Disorders and Atopy in Cotton, Wool, and Other Textile Mill Workers in Denmark. American Journal of Industrial Medicine, 22, 163-184. http://dx.doi.org/10.1002/ajim.4700220204

[17] Rongo, L., Barten, F., Msamanga, G., Heederik, D. and Dolmans, W. (2004) Occupational Exposure and Health Problems in Small-Scale Industry Workers in Dar es Salaam, Tanzania: A Situation Analysis. Occupational Medicine, 54, 42-46. http://dx.doi.org/10.1093/occmed/kqh001

[18] Motamedzade, M. and Moghimbeigi, A. (2012) Musculoskeletal Disorders among Female Carpet Weavers in Iran. Ergonomics, 55, 229-236. http://dx.doi.org/10.1080/00140139.2011.582539 